UDK 81'255.4:811.133.1 Krleža, M. https://doi.org/10.21857/9e31lhn0lm Izvorni znanstveni članak Rukopis primljen 8. V. 2017.

Biljana Stojaković Prihvaćen za tisak 24. IX. 2017.

Tehničko veleučilište u Zagrebu

Vrbik 8, HR-10000 Zagreb

bstojakovic@tvz.hr

\title{
REINTEGRACIJA STILOGENIH GALICIZAMA U FRANCUSKOM PRIJEVODU KRLEŽINIH DJELA
}

Leksičko posuđivanje je uobičajena pojava među jezicima. Tako je i hrvatski jezik posuđivao riječi iz raznih jezika, uključujući i francuski. Međutim, kako je zbog povijesnih i geopolitičkih razloga hrvatski jezik bio dugi niz godina pod snažnim utjecajem njemačkog jezika, većina francuskih posuđenica došla je u hrvatski preko njemačkog jezika. U leksičkom posuđivanju uobičajena je pojava da se posuđenica preuzima uglavnom u suženom značenju (smanjen broj značenja i/ili suženo značenjsko polje). Tako je većina njemačkih replika francuskih modela već imala promijenjeno značenje i kao takve su preuzete $u$ hrvatski jezik. Ipak, zbog čimbenika izvanjezične stvarnosti, manjem broju njemačkih replika prošireno je značenje pa su takve preuzete u hrvatski jezik.

Dolaskom u hrvatski jezik većina francuskih posuđenica pretrpjela je prilagodbu na fonološkom, morfosintaktičkom i semantičkom planu i integrirala se u sustav jezika primatelja. Brojne su studije koje se bave istraživanjem integracije stranih riječi u sustav jezika primatelja, ali rijetke su one koje se bave reintegracijom posuđenica u sustav jezika davatelja. Istraživanje reintegracije stilogenih Krležinih galicizama u sustav francuskog jezika ukazalo je na brojne prepreke njihovoj reintegraciji, što govori o opsegu promjena koje posuđenice trpe u prilagodbi jeziku primatelju. Pri tome je utvrđena značajna uloga njemačkog jezika kao jezika posrednika. Zbog semantičkog odmaka galicizama u odnosu na modele prevoditelji su morali primijeniti različite postupke prevođenja Krležinih djela na francuski jezik kako bi uspješno prenijeli piščevu misao i postigli stilogenost izraženu njegovim galicizmima. 


\section{Uvod}

Ovaj se rad bavi analizom reintegracije Krležinih galicizama u francuskom prijevodu njegovih djela na stilističkoj razini i predstavlja dio rezultata sveobuhvatnije studije ${ }^{1}$ čiji je cilj bio dokazati da se samo analizom reintegracije posuđenica $u$ ishodišni jezik može steći objektivan uvid u stupanj njihove prilagodbe jeziku primatelju. Naime, jednostranom analizom posuđenica $u$ jeziku primatelju ne stječe se potpuno saznanje o opsegu promjena koje posuđenice trpe u prilagodbi stranome jeziku. Nalazi istraživanja govore u prilog brojnim preprekama reintegraciji. I upravo analizom tih prepreka dolazi se do spoznaja o razini prilagodbe posuđenica novom jezičnom okruženju te o stupnju udaljenosti od kolijevke jezika davatelja. Rezultati analize pokazali su da pri ulasku u hrvatski jezik većina galicizama teži prilagodbi hrvatskom jezičnom sustavu. U reintegraciji $u$ francuski jezik događaju se različite pojave: galicizmi se reintegriraju, zamjenjuju se drugim riječima ili se izostavljaju u prijevodu. Uzroci preprekama reintegraciji su različiti: razlike u morfosintaktičkim sustavima hrvatskog i francuskog jezika, relativnost značenja riječi, distribucijska asimetrija, različiti lingvistički statusi riječi, dijakronijski diskontinuitet, različito poimanje izvanlingvističke stvarnosti i prevoditeljska sloboda. Pri tome je značajan utjecaj jezika posrednika.

U istraživanju smo primijenili načela kontrastivne analize, teorije jezika u kontaktu, stilistike i teorije prevođenja.

\subsection{Korpus galicizama}

Korpus se sastoji od galicizama koje smo istraživali u sljedećim Krležinim djelima i njihovim prijevodima:

- Banket u Blitvi² - Banquet en Blituhanie (prijevod: Mauricette Sullerot-Begic)

- Povratak Filipa Latinovicza ${ }^{3}$ - Le Retour de Philippe Latinoviz (prijevod: Mila Djordjevic i Clara Malraux)

- Na rubu pameti ${ }^{4}$ - Je ne joue plus (prijevod: Janine Matillon)

- Hrvatski bog Mars ${ }^{5}$ - Mars Dieu Croate (prijevod: Janine Matillon i Antun Polanšćak)

1 Stojaković, Biljana. 2012. Krležini galicizmi u francuskom prijevodu njegovih djela (doktorski rad pod mentorstvom dr. sc. Zeljka Klaića).

2 U daljnjem tekstu: BB.

3 U daljnjem tekstu: PFL.

4 U daljnjem tekstu: NRP.

5 U daljnjem tekstu: HBM. 
Biljana Stojaković: Reintegracija stilogenih galicizama u francuskom prijevodu...

FILOLOGIJA 70(2018), 107-133

- Sprovod u Theresienbourgu ${ }^{6}$ - Enterrement à Theresienbourg (prijevod: Antun Polanšćak)

Ti galicizmi se mogu podijeliti u dvije skupine: francuske posuđenice, $t j$. tuđice koje nisu adaptirane ni integrirane u sustav hrvatskog jezika i francuske posuđenice koje su adaptirane i integrirane u sustav hrvatskog jezika. Pri tome smo utvrdili značajan utjecaj jezika posrednika, najčešće njemačkog jezika.

\section{Adaptacija i integracija francuskih posuđenica u hrvatski jezik; reintegracija u francuski jezik}

Jezično posuđivanje počinje kad se model iz jezika davatelja (ovdje francuskog) prenese $u$ jezik primatelj (ovdje hrvatski). Prije konačne integracije $\mathrm{u}$ sustav hrvatskog jezika, model prolazi različite oblike adaptacije, od kompromisne replike do replike. ${ }^{7}$ Procesom jezičnog posuđivanja upravljaju dvije operacije: supstitucija i importacija (Filipović 1986:41). Haugen tako tvrdi da se svaki aspekt modela koji se zamjenjuje nekim ekvivalentom iz sustava jezika primatelja naziva supstitucija (substitution), a svaki aspekt koji je replika preuzela predstavlja importaciju (importation) (Haugen 1950:212). Supstitucija je znatno češća pojava nego importacija. U procesu jezičnog posuđivanja javlja se također i interferencija ili lingvističko preklapanje, tj. prenošenje nekog aspekta modela na repliku. Stupanj interferencije ovisi o stupnju integriranosti modela $u$ jezik primatelj.

Sveobuhvatna studija je pokazala da su rijetki galicizmi koji se u svim svojim aspektima podudaraju s francuskim modelom i to zbog različitih čimbenika koji tome pridonose na putu posuđenice od jezika davatelja do jezika primatelja. Međutim, jedini način da se dobije sveobuhvatni uvid $\mathrm{u}$ razmjere promjena koje posuđenica trpi na tome putu jest da se istraže mogućnosti reintegracije te posuđenice u jezik davatelj, kao i prepreke toj reintegraciji. ${ }^{8} \mathrm{U}$ ovom radu istražili smo te procese na stilističkoj razini lingvističke analize.

$6 \quad$ U daljnjem tekstu: ST.

7 Treba svakako istaknuti utjecaj jezika posrednika. Naime, samo je mali broj francuskih posuđenica ušao u hrvatski jezik izravno. Sve su ostale ušle preko jezika posrednika, najčešće njemačkog, u kojem je francuska posuđenica prošla sve oblike i stupnjeve adaptacije i konačnu integraciju u sustav njemačkog jezika. Tako je, zapravo, hrvatski posuđivao u najvećoj mjeri njemačke replike francuskih modela.

8 »Les conditions de leur (des emprunts) réintégration dans la langue prêteuse dépendent du degré d'adaptation qu'ils ont atteint aux différents plans de la langue emprunteuse, ou, en d'autres termes, du degré de perte des attaches avec leur système d’origine« (Klaić 1982-1983:191). 


\section{Stilistička razina analize}

Na ovoj razini bavili smo se lingvostilističkom analizom Krležinih galicizama $u$ francuskim prijevodima njegovih djela, tj. analizom stilogenih galicizama koji su djelomično reintegrirani ili nisu uopće reintegrirani $u$ francuski prijevod i analizom uzroka te pojave. Analizirali smo uporabu galicizama u funkciji Krležina stila na različitim razinama, uzimajući u obzir osobitosti književnoumjetničkog funkcionalnog stila.

\subsection{Književnoumjetnički (beletristički) stil}

Jedna od šest funkcija jezika je poetska (estetska) funkcija (Jakobson 1987:66). Ta je funkcija karakteristična prvenstveno za književnoumjetničke tekstove, koje odlikuje književnoumjetnički stil. Književnoumjetnički stil je stil pojedinca, to je »najbogatiji i najsloženiji vid književnoga jezika i jezika zajednice uopće« (Antoš 1974:18). »Književnoumjetnički je stil najindividualniji funkcionalni stil standardnoga jezika. U njemu je individualna sloboda najveća « (Silić 2006:100). U svojoj raspravi o književnoumjetničkom stilu Marina Katnić Bakaršić daje zanimljivu usporedbu: »U književnoumjetničkom tekstu, pod uvjetom da je to $\mathrm{u}$ funkciji estetske, umjetničke vrijednosti, pisac, emitent poruke smije slijediti primjer Humpty Dumptyja iz Alise u zemlji čuda i reći: `Kada ja upotrijebim riječs, reče Humpty Dumpty, ... >ona znači točno ono što ja odlučim da znači ni manje ni više«« (Katnić-Bakaršić 1999:38).

Upravo sva ljepota, složenost, individualnost i originalnost takvog stila ogleda se u djelima Miroslava Krleže.

\subsection{Posljedice jezičnog raslojavanja na književnoumjetnički stil}

Nijedan jezik nije homogen, tj. jezik se raslojava »zavisno od toga kakvu ulogu odnosno funkciju u društvu i kulturi ima, o kakvoj temi saopštava, ko njime govori ili piše, s kim, kada ga, gde i u kojoj prilici, tj. situaciji upotrebljava, s kojim ciljem, itd.« (Radovanović 1979:63). To znači da jezik i u svom govornom i u svom pisanom izričaju raspolaže različitim sredstvima i koristi različite načine njihove uporabe, što doprinosi stvaranju različitih jezičnih slojeva, koji uključuju stilske, varijantske, dijalekatske, sociolekatske, idiolekatske, žargonske i druge varijacije. Ta se pojava naziva "jezično raslojavanje" i označava procese koji se mogu svesti pod nekoliko tipova: funkcionalno, socijalno, individualno i teritorijalno jezično raslojavanje. Socijalnim raslojavanjem nastaju sociolekti u kojima se očituju razlike između pojedinih društvenih skupina, slojeva, itd. Te se razlike javljaju najčešće na leksičkoj razini, ali i na svim ostalim razina- 
Biljana Stojaković: Reintegracija stilogenih galicizama u francuskom prijevodu...

FILOLOGIJA 70(2018), 107-133

ma. U književnoumjetničkom djelu upotrebljavaju se elementi sociolekata radi postizanja posebnog stilskog efekta. »Outre leurs caractères affectifs naturels, les faits d'expression ont la faculté d'évoquer les "milieux" où leur emploi est le plus naturel et le plus fréquent, autrement dit, de produire des effets par évocation, qui ne se révèlent que par contraste avec la langue commune« (Bally 1951:203). U književnoumjetničkom stilu također je prisutna i uporaba tuđica radi postizanja posebnog stilskog efekta, tj. lokalne boje (kolorita): »Strani jezik služi piscu za prikazivanje jedne epohe, društvene sredine ili za govornu karakterizaciju likova. Takva je funkcija njemačkog jezika u govoru junaka Krležinih drama« (Katnić-Bakaršić 1999:41); »M. Krleža njemačkim leksikom karakterizira svoje bogate građane (Glembajevi) « (Antoš 1974:91). Ali, ne radi se samo o njemačkom jeziku, jer Krležini junaci obilato koriste i galicizme. B. Franolić tako ističe: »les innovations de Šenoa en matière de vocabulaire et les néologismes littéraires de provenance et d'inspiration française de Matoš apparaissent bien timides de ceux de Krleža qui a émaillé sa prose de centaines de mots d'emprunt et de mots fantaisistes forgés de toutes pièces « (Franolić 1975:108).

\subsection{Osebujnost Krležina jezičnog izraza}

U književnosti stil je »skup jezičnih karakteristika po kojima se pojedinci razlikuju - osnova njihovog osobnog lingvističkog identiteta « (Crystal 1994:66). Stil Miroslava Krleže je jedinstven. Krleža je bio velik erudit i poznavatelj mnogih svjetskih jezika. »Govorio je nekoliko europskih jezika - osim materinskoga služio se njemačkim, francuskim, mađarskim, ruskim i talijanskim, jedino nije dobro poznavao engleski. Putovao je po Europi, poznavao je Austriju i Mađarsku, osobito Beč i Budimpeštu. Osim tih država, poznavao je i Srbiju, Francusku - osobito Pariz - a bio je i u Njemačkoj, Rusiji i Italiji. Dulje je vremena živio u Čehoslovačkoj i Poljskoj. Njegovi ga eseji otkrivaju kao kozmopolitskog Europljanina. Njemačka, francuska i mađarska književnost bile su mu jednako bliske kao južnoslavenske« (Lauer 2013:16). I Bratoljub Klaić u prikazu prvog poglavlja Krležina romana Zastave kaže da Krleža »operira njemačkim, francuskim, talijanskim, engleskim, mađarskim, latinskim i grčkim jezikom pored mnogobrojnih realija sa svih područja ljudske djelatnosti« (Klaić 1972:261). U tom prikazu obrađen je ukupan korpus stranih elemenata $\mathrm{u}$ tekstu romana i Bratoljub Klaić je utvrdio da je gotovo nemoguće snalaziti se u Krležinim tekstovima bez priručnih rječnika, leksikona i enciklopedija. Pa ipak, Klaić je izrazio zadivljenost lakoćom pisanja i osebujnošću književnog izraza: »Tako može pisati samo pisac koji zaslužuje da ga zovemo 
Biljana Stojaković: Reintegracija stilogenih galicizama u francuskom prijevodu...

FILOLOGIJA 70(2018), 107-133

Učiteljem« (Klaić 1972:276). Krunoslav Pranjić naziva Krležu enciklopedistom prije svega zbog jedne od njegovih bitnih stilsko-kompozicijskih konstanti: »nebrojene... često metaforizirane asocijacije, tematskostilske ekskurzije u najrazličitija područja ljudskog iskustva i stečenih spoznaja: u područja povijesno povijesna, likovno ili glazbeno povijesna, medicinska, geološko-paleontološka, gnoseološka... Manifestira se to metaforiziranom upotrebom onoga što se nazivlje terminus technicus iz svih tih mahom znanstvenih područja« (1986:151). Osim toga, Krleža je u nekim svojim djelima pokazao i privrženost staroj književnogovornoj tradiciji kajkavskoga jezika. Poznavao je i jezike koji su se govorili u starom Zagrebu: »agramski kuhinjski hrvatski jednostavnih ljudi, agramski njemački obrazovanih slojeva. Oživio je i jedan i drugi u svojim djelima. Danas postoji samo malen broj onih koji bi ih još mogli razumjeti« (Lauer 2013:16).

\subsection{Pristup analizi}

»Krležin stil zlatan je majdan u kojem će se čak brigadno, institutski moći rudariti godinama; iz majdana bi trebalo izvući sve što je bilo unapređivalo ili potvrđivalo hrvatski književni izraz; iz majdana višestruko vrijedi sistemski, akribično, znanstveno vrijedi kompletirati i monografsku tipologiju svih stilskih postupaka, i popis metafora, i rekonstrukciju nazora o svijetu, i rječnik leksičkih inovacija « (Pranjić 1986:150).

Mi smo pristupili "rudarenju" tog "majdana" lingvostilističkom analizom Krležinih galicizama u francuskom prijevodu. Za svrhovitost ove studije i potvrdu njezine teze bitni su analiza i prikaz stilogenih galicizama koji nisu reintegrirani $u$ francuskom prijevodu.

\subsection{Prevođenje književnoumjetničkog teksta}

E. Nida je terminima komunikacijske teorije definirao prevođenje »kao nalaženje najbližeg prirodnog ekvivalenta u jeziku cilju za obavijest izraženu u izvornom jeziku« (Ivir 1985:36). O prevođenju i njegovoj kvaliteti napisane su mnoge rasprave, npr. »Interlingual translation or translation proper is an interpretation of verbal signs by means of some other language« (Jakobson 1959/2004:139); »prevođenjem se dobiva najbliži ekvivalent, a to znači ne apsolutno, nego relativno jednakovrijedna poruka« (Ivir 1985:36); »Prijevod... mora biti proziran, on se ne smije zamjećivati« (Ivir 1985: 56); »Prijevod mora odgovarati smislu izvornika i izraziti njegov osjećajni stupanj« (Guberina 1967:63).

Rasprave o prevođenju često uključuju pitanje prevođenja umjetničkih tekstova, tj. »diskusiju... o umjetničkom, odnosno neumjetničkom ekviva- 
Biljana Stojaković: Reintegracija stilogenih galicizama u francuskom prijevodu...

FILOLOGIJA 70(2018), 107-133

lentu prijevoda u uspoređenju s originalom... književno-umjetničku vrijednost prijevoda moramo imati pred očima kao prvu (teoretsku) pretpostavku i kao posljednju (primijenjenu) pretpostavku« (Guberina 1967:58).

Stilistika je znanstvena disciplina koja daje podatke o umjetničkom usklađivanju vrijednosti riječi u različitim jezicima.

Charles Bally je uveo u stilistiku pojam afektione vrijednosti izraza: »elle (stylistique) étudie la valeur affective des faits du langage organisé, et l'action réciproque des faits expressifs qui concourent à former le système des moyens d'expression d'une langue « (1951:1). Guberina također govori o stilističkoj vrijednosti jezičnog izraza i o teškoćama na koje prevoditelj nailazi kad želi u prijevodu postići stilističku vjerodostojnost izraza: »Bez sumnje najteže je izraziti osjećajni sadržaj originala. Golu misao, sadržaj, nije teško izraziti, ako poznajemo drugi jezik, ali finoću i stupanj osjećajnog sadržaja izraza treba tražiti u neograničenom nizu glasovnih i sintaktičkih mogućnosti dotičnoga jezika« (Guberina 1967:67).

Potpuno svjesni složenosti i zahtjevnosti prijevodnog procesa književnog teksta, a naročito Krležina, ${ }^{9}$ upustili smo se u kontrastivnu analizu stilogenih galicizama u hrvatskom tekstu i njegovom prijevodu na francuski. Dali smo i procjenu o postignutoj ekvivalenciji afektivne vrijednosti izraza u prijevodu.

\subsection{Fonostilistička razina analize}

Osnovu fonostilističkog istraživanja čine istraživanja u područjima apelativne i ekspresivne fonologije. »Apelativna fonologija ima za zadatak proučavanje fonetskih varijanti s obzirom na utisak koji one treba da ostave na slušaoca... ekspresivna fonologija promatrala bi način izgovora, intonaciju, pauze i sl. sa stanovišta govornika« (Katnić-Bakaršić 1999:80).

Na tragu ideje o postizanju effet par évocation, Bally konstatira da fonetske navike govornika upućuju na društvenu sredinu kojoj on pripada; izgovor je vrsta društvene etikete prema kojoj se ljudi rangiraju u društvu (Bally 1951:232). Tako u Banketu u Blitvi Krleža pripovijeda priču o nesretnom dječaku koji umre sam na noćnoj posudi dok njegova majka ima rendez-vous:

Mali Öžen izdahnuo je banalno, u kuhinji, na noćnom loncu... - Le petit Eugène était mort banalement, dans la cuisine, sur son pot de chambre... - ...zapalili su svjetlost po čitavom stanu, otvorili sva vrata, sve ormare (jer se Öžen običavao sa-

9 »Ni jednom Krležinom nasljedniku nije uspjelo oponašati ni nastaviti taj stil... On je velika poteškoća svim prevoditeljima. Strani čitatelj mora se zadovoljiti tek skromnim nadomjescima« (Lauer 2013:17). 
Biljana Stojaković: Reintegracija stilogenih galicizama u francuskom prijevodu...

FILOLOGIJA 70(2018), 107-133

krivati po ormarima) i na kraju našli su ga u kujni, na noćnom loncu, kako se šćućurio, već potpuno hladan. - ...Ils ont allumé la lumière dans toutes les pièces, ouvert toutes les portes, toutes les armoires (car Eugène avait l'habitude de se cacher dans les armoires), et enfin ils l'ont trouvé dans la cuisine, sur son pot, tout recroquevillé, déjà complètement froid. - Ono o malom Öženu na noćnom loncu, na primjer, ono je izvan svake sumnje fantazija. - L'histoire du petit Eugène, son pot dans la cuisine, par exemple, c'est sans doute de la pure imagination. (BB)

Krleža ispisuje ime dječaka u transkripcijskom obliku francuskog izgovora imena kako bi postigao lokalni kolorit, tj. prikazao jezične i govorne navike ljudi visokog društva određenog vremena. ${ }^{10}$ Procjenjujemo da $\mathrm{u}$ francuskom prijevodu nije postignut taj effet par évocation, jer čitatelju francuskog teksta samo ime Eugène nije ni na koji način stilogeno. ${ }^{11}$

Na ovoj razini tragali smo i za fonetsko-fonološkim figurama u Krležinu tekstu i naišli na zanimljive primjere aliteracije. »U svim tipovima tekstova kod kojih postoji poetska funkcija jezika, emitent poruke može posegnuti za postupkom slikanja glasovima« (Katnić-Bakaršić 1999:81). »Pridonosi li ponavljanje istih konsonanata na početku uzastopnih riječi u stihu ili u prozi većemu slaganju zvuka i značenja, aliteracija je stilogena« (Antoš 1974:39).

U kumulativnom nabrajanju ${ }^{12}$ u sljedećem primjeru, u nizu galicizama i izvorno hrvatskih riječi, ostvarena je aliteracija uzastopnim ponavljanjem suglasničkih skupina ka-, ke-, ko-. Na taj način je čitatelju dočarana situacija u kojoj se čuje kas konja i zveckanje sablji. U francuskom prijevodu ostvarena je odgovarajuća aliteracija, kojoj su samo jednim dijelom doprinijeli reintegrirani galicizmi:

10 U romanu Na rubu pameti uporaba galicizama u iskrivljenom francuskom izgovoru postaje stilogena. Krleža je to napravio radi karakterizacije lika, tj. ironičnog prikaza jednog od pripadnika tzv. elite - čovjeka koji upotrebljava francuske riječi, a da ne zna ni njihov pravilan izgovor, ni njihovo značenje. U francuskom je prijevodu na isti način postignut sličan efekt:

...naivčina koja izgovara sebi samome neobično impozantne $i$ tajanstvene riječi 'okassion', 'Žofer', 'mala ententa', 'tresor'... - ...homme simple usant de mots qui ne le sont pas et qui ne laissent d'impressionner, occassion, 'jofer', 'petite ententa', 'tressor'... // ...on je ugledan privrednik, on je naše gore list, on ima svoga 'žofera', svoje 'portraete'... - ...c'est un industriel en vue, et avec ses 'jofers', ses 'portraete'... (NRP).

11 Prevoditelji su u takvim slučajevima pribjegli jedinom mogućem rješenju: čitatelju francuskog prijevoda su u bilješci na dnu stranice naznačili da je određena riječ u izvornom hrvatskom tekstu napisana na francuskom jeziku.

12 »Izražajnosti riječi služi i nabrajanje (kumulacija, amplifikacija)« (Antoš 1974:68). Kumulacija je stilska dominanta kod Krleže. Stilska dominanta podrazumijeva onaj element stila nekog teksta kojem su potčinjeni svi drugi njegovi elementi (Sławiński 1985:90). 
Biljana Stojaković: Reintegracija stilogenih galicizama u francuskom prijevodu...

FILOLOGIJA 70(2018), 107-133

Bezglasno, kao u koroti tamna, približavala se sa dna Bulevara Kristijana Barutanskoga kavalerijska brigada Chevau-légersa, na crnim konjima, tri eskadrone, jedna iza druge, u četvororedu, na pravilan razmak po dvanaest metara, tri puta po šezdeset konjanika, stotinu i osamdeset konja... u tri karea, sve rep za repom, kaciga do kacige, sablja do sablje, karabinka do karabinke... na čelu brigade, na svojoj pomeranskoj kobili Rozamundi, kavalerijski major Hijacint Kerinis... Sans bruit, dans le deuil de ses contours sombres s'approchait, venant du fond du boulevard Kristian-Baroutanski, une brigade de cavalerie de chevau-légers, sur des chevaux noirs; trois escadrons en rang par quatre, l'intervalle réglementaire de douze mètres, trois fois soixante cavaliers, cent quatre-vingts chevaux... en trois carrés, tous queue contre queue, casque contre casque, sabre contre sabre, carabine contre carabine... A la tête de cette masse de sabots, de queues, d'acier et d'éperons, dans le cliquetis des lourdes épées de cavalerie chevauchait le lieutenant-colonel Hyacinthe Kérinis, monté sur sa jument poméranienne Rosalinde. (BB)

\subsection{Morfostilistička razina analize}

»Morfostilistička razina proučava funkcionalno-stilsku markiranost morfoloških kategorija i ekspresivne vrijednosti tih kategorija« (Katnić-Bakaršić 1999:86).

Na ovoj razini naše smo istraživanje usmjerili na stilogenu upotrebu augmentativa naivčina ${ }^{13}$ kod Krleže. U raspravi o afektivnoj vrijednosti sufiksa i prefiksa, Antoš ističe da su »deminutivi i augmentativi morfostilističke varijante koje se od osnovne riječi razlikuju po afektivnosti« (1974:63).

Naivčina sadržava sufiks -ina koji nosi augmentativno-pejorativno značenje. Osnovni oblik pridjeva naif, ve ima sljedeća značenja: 'naivan', 'bezazlen', 'djetinjast', 'neiskusan'; 'prostodušan', 'priprost'; 'ograničen', 'priglup' (Putanec 1974:539). U rečenicama koje slijede augmentativ naivčina izražava krajnji stupanj kvalitete značenja 'priprost', 'ograničen' i 'priglup'. Zbog ograničenja u flektivnim mogućnostima, u francuskom morfološkom sustavu ne postoji odgovarajući gramatički oblik augmentativa. Tako $\mathrm{u}$ francuskom prijevodu prve rečenice nalazimo osnovni oblik pridjeva naïf i smatramo da na taj način nije prenesena ekspresivna vrijednost izražena galicizmom naivčina. U prijevodu druge rečenice dogodila se supstitucija izrazom homme simple, koji doduše prenosi sem 'priprost',

13 NAIF, n.m. n(1) (Le Petit Robert 1996:1468)

naivac I $S_{0}=$ neškolovan umjetnik

$i z v$ naivnik $\mathrm{I} \mathrm{S}_{0}=$ naivan čovjek, lakovjernik, budala, zvekan

izv naivčina uveć.

izv naivko, naivka odmila. 
Biljana Stojaković: Reintegracija stilogenih galicizama u francuskom prijevodu...

FILOLOGIJA 70(2018), 107-133

ali je također lišen ekspresivne vrijednosti sadržaja riječi naivčina.

Ja sam se uopće rodio kao naivčina, poštenja mi, i ja ne znam da li mi vjerujete, ja sam ubio onu nesretnu Violetu. - Je vous assure que je suis né nä̈f et, je ne sais pas si vous me croirez, mais j'ai tué cette malheureuse Violette. (BB)

...naivčina koja izgovara sebi samome neobično impozantne i tajanstvene riječi 'okassion', 'žofer', 'mala ententa', 'tresor'... - ...homme simple usant de mots qui ne le sont pas et qui ne laissent d'impressionner, occassion, 'jofer', 'petite ententa', 'tressor'... (NRP)

\subsection{Semantostilistička razina analize}

Na ovoj razini učinit ćemo osvrt na relativnost značenja riječi, distribucijsku asimetriju, različite lingvističke statuse riječi i na stilske figure koje nisu reintegrirane $\mathrm{u}$ francuski jezik.

\subsubsection{Relativnost značenja riječi}

Značenje riječi se mijenja tijekom razvoja jezika. Riječi nestaju iz leksika ili njihova uporaba zvuči arhaično, zamjenjuju ih druge riječi itd. Osim toga, značenje riječi mijenja se i u procesu posuđivanja. Tako ponekad postoje veliki otkloni u značenju replike u odnosu na značenje modela, što je često posljedica utjecaja jezika posrednika.

Kao što smo već naveli, uporaba tuđica u određenom društvenom miljeu može biti oznaka pripadanja toj sredini i imati funkciju postizanja effet par évocation. Tako Krležini likovi koji pripadaju višoj društvenoj klasi u govoru često koriste adaptirane ili neadaptirane strane riječi pa tako i galicizme, unatoč postojanju hrvatskih inačica. U francuskom prijevodu neki galicizmi su reintegrirani, ali oni gube svoju dimenziju stilogenosti. Navodimo niz primjera uporabe galicizama u takvoj funkciji:

$O$, veoma ste ženerozni. - Oh! vous êtes très généreux. (BB) (pored hrv. velikodušan)

...zapravo, on se danas i ne sjeća da li mu je štamparija vratila rukopis ili ga je on one nervozne noći ostavio kod metteura? - ...il ne se souvient plus aujourd'hui si l'imprimerie lui avait rendu son manuscrit ou s'il avait, cette nuit de tension nerveuse, laissé chez le metteur en page. (BB) (pored hrv. slovoslagač)

Tajna moje vlastite pasivnosti mogla bi se objasniti i mojim glupim i neprijatnim metjeom. - Le secret de cette passivité, je le trouve dans le métier maussade et imbécile qui était le mien. (NRP) (pored hrv. zvanje, zanimanje)

Dobro sam poznavao tu hohštaplersku obitelj po pričanju svoje supruge koja je s njima bila u kuzenskim odnosima, i znajući iza kulisa... - Je connaissais bien cette famille de rastaquouères grâce aux ragots de ma femme qui est leur cousine, et je savais ce qui se passait dans la coulisse... (NRP) // - ...tako je tu vijest preuveličao kuzen moje supruge... - ...puis le cousin Egon Sarvach l'a étoffée... 
Biljana Stojaković: Reintegracija stilogenih galicizama u francuskom prijevodu...

FILOLOGIJA 70(2018), 107-133

(NRP) // Grofica Orcyvar (koju su tu pod liepachovskim krovom - ne zna se zašto - zvali kuzinom), ...stara dama od skoro sedamdeset godina... - La comtesse Orcyval, principal personnage de Kostanjevets (que, sous ce toit des Liepach l'on nommait, on ne sait pourquoi, cousine)... était une vieille dame de près de soixante-dix ans... - Pa onda njen kuzen po majci, vitez Urban... - Puis encore son cousin du côté maternel, le chevalier Urban... (PFL) // Pod kišom indiskretnih pogleda staromodnih svastika, tetaka, mamica i kuzina... - Sous la pluie des regards indiscrets des belles-scurs, tantes, mères et cousines à l'ancienne mode... (BB) (pored hrv. rođak/rođački)

...i iz čitavog vašeg stava, iz vaše attitude spram njegova umjetničkog djela osjećao se dubok unutrašnji respekt! - ...et toute votre attitude trahissait un profon respect intérieur pour son cuvre artistique! (NRP) // On se ne smije dovesti u atitudu slabića koji se tu pred svima pere kao krivac za ovu smrt. - Il n'était conscient que d'une seule chose: de la nécessité de ne pas se montrer faible, comme si c'était lui le responsable de cette mort. (ST) (pored hrv. stav, stajalište)

I guvernanta sa svojom nesnosnom: occupation quotidienne i njegova mama... - Et la gouvernante avec son inepte: 'occupation quotidienne', et sa mère... (PFL) (pored hrv. svakidašnji posao)

...kao da nastavlja upravo ondje gdje ga je prekinuo dolazak ove Bobočkine neočekivane i u svakom pogledu suvišne vizite. - ...il semblait reprendre une conversation interrompue par l'arrivée de ce visiteur inattendu. // A osim toga i stari Liepach je dolje u viziti. - De plus, le vieux Liepach était chez sa mère, en visite. (PFL) (pored hrv. posjet)

Taj barokni jezuitski antre... - Cette entrée de style jésuite... (PFL) (pored hrv. ulaz)

Merci, ne pleše mi se više! Hvala lijepa! - Je n'ai plus envie de danser. Merci beaucoup. (BB) (pored hrv. hvala)

Tamo se mnogo bave slikarstvom, gospođa Ingrida trati svoje dane na vernissageima, imaju li pojma oni snobovi kakva se glupa propaganda tjera u njihovo ime? Ils font beaucoup de peinture là-bas. Madame passe ses journées à des vernissages. Est-ce que ces snobs ont une idée de la propagande imbécile qui se fait en leur nom? (BB) (pored hrv. otvorenje izložbe).

Osim tuđice vernissage, Krleža u Banketu u Blitvi koristi i potpuniji francuski izraz jour de vernissage ${ }^{14}$ kako bi označio događaj koji se odvija navečer. To značenje je posuđeno iz izraza »jour d'ouverture d'une exposi-

14 VERNISSAGE, n.m. n(2) (Le Petit Robert 1996:2375)

vernisaža I $S_{0}=$ lakiranje slika; razgledavanje slika uoči izložbe; dan otvorenja izložbe (jour de vernissage kod Krleže)

(preko njem. (die) Vernissage izložba novih slika živućeg slikara; (općenito) predstavljanje umjetnika publici)

var. vernisaž (Krleža)

jour (de vernissage). 
Biljana Stojaković: Reintegracija stilogenih galicizama u francuskom prijevodu...

FILOLOGIJA 70(2018), 107-133

tion de peinture«. Dakle, došlo je do semantičkog pomaka francuske riječi jour. U prijevodu je izraz skraćen:

...a kako su obojica bili još pod dojmom Larsenovog jour de vernissagea... - ...et comme tous deux étaient encore sous l'impression du vernissage de Larsen... (BB)

Prema Franoliću značenje francuskog modela jour suženo je, tj. specijalizirano u galicizmu žur: »rénion mondaine qui a lieu dans l'après-midi« (Franolić 1976:215). To značenje je posuđeno iz francuskog izraza jour de réception, tj. iz njegova skraćenog dijela jour. Franolić definira galicizam žur još jednim značenjem: 'surprise-partie; réunion dansante privée, soirée dansante'. Kod njega nalazimo i izraz žur-fiks: »jour de semaine déterminé d'avance pour recevoir des invités.«

Andrić navodi srpski žargonski izraz žurka, naročito u upotrebi kod mladih ljudi (1976:51).

Iako je u sljedećem primjeru upotrijebljen u izvornoj grafiji, galicizam $\check{z} u r$ smatra se hrvatskim galicizmom s gore navedenim značenjem. Stoga je u prijevodu na francuski došlo do supstitucije riječju koja je po svome značenju najbliži ekvivalent našem galicizmu.

Sami najbolje znate kako na jourovima kod toga našeg reprezentativnog "genija« izgleda... - ...vous savez mieux que personne à quoi ressemblent les soirées données par notre représentatif »génie«... (BB)

Zbog istih semantičkih razloga u primjeru koji slijedi došlo je do promjene sintaktičkog modela:

...tu naše dame peru rublje u utorak, a imaju svoje žurove u petak... - ...ces dames font la lessive le mardi et reçoivent le vendredi... (BB)

Galicizam interijer ${ }^{15}$ je u primarnoj adaptaciji preuzeo samo dio značenja francuskog modela intérieur $n$. adj., tj. značenje galicizma je znatno suženo u odnosu na značenje modela intérieur, koji inače ima funkciju imenice i pridjeva $u$ francuskom jeziku. U prvom od svojih značenja u velikoj se mjeri podudara s jednim od značenja francuskog modela intérieur: »Habitation considérée dans son aménagement intérieur. $\rightarrow$ chez(-soi), foyer « (Le Petit Robert 1996:1196). To prikazujemo sljedećim primjerom:

Kod njega na londonskom poslanstvu bili su intérieuri, prijemi, posluga, coijeće, sve comme il faut. (BB)

Unatoč činjenici da se značenjsko polje jednog od značenja galicizma

15 INTÉRIEUR n.m. n(4) interijer (Krleža) (Le Petit Robert 1996:1196)

I $_{1 \mathrm{n}}\left(\neq 1 . S_{1 \mathrm{f}}, 3 . \mathrm{S}_{1 \mathrm{f}}\right)=$ unutrašnjost neke prostorije, unutrašnji uređaj; snimanje filmskih scena u zatvorenom prostoru; slika koja prikazuje unutrašnjost arhitektonskog objekta ili prizor iz života u domu (Klaić 1982:218)

var intérieur (Krleža). 
Biljana Stojaković: Reintegracija stilogenih galicizama u francuskom prijevodu...

FILOLOGIJA 70(2018), 107-133

interijer i modela intérieur preklapaju, u sljedećem primjeru prevoditeljica se $\mathrm{u}$ francuskoj verziji poslužila supstitucijom:

Chez lui, à l'ambassade de Londres, tout, la décoration, les receptions, les domestiques, les fleurs, était comme il faut. (BB)

Naime, jedna od specijalizacija (suženja) značenja francuskog modela intérieur u hrvatskom galicizmu je 'unutrašnji uređaj'. To značenje se odnosi na estetsko uređenje unutarnjeg prostora, dekoriranje, pa je prevoditeljica $u$ francuskom prijevodu upotrijebila upravo riječ décoration.

U prijevodu romana Povratak Filipa Latinovicza galicizam interieur također nije reintegriran, nego je zamijenjen francuskom riječi description:

...po njenim putovanjima, po interieurima njenih stanova, po njenim psima $i$ konjima $i$ automobilima vidjelo se da nije bila oduvijek samo to... - A en juger... d'après les récits de ses voyages, les descriptions de ses maisons, de ses chiens, de ses chevaux, de ses automobiles, il était clair qu'elle avait connu une autre vie. (PFL)

Dakle, i ovdje je Krleža mislio na 'unutrašnji uređaj', tj. ako parafraziramo na sljedeći način: »sudeći prema izgledu njenih stanova«, nalazimo logičnim francuski prijevod: »d'après... les descriptions de ses maisons« (PFL).

Galicizam soigniran ${ }^{16}$ je $\mathrm{u}$ primarnoj adaptaciji preuzeo samo prvo značenje (od 3) francuskog modela soigné, ée adj.: »1. Dont on a pris soin; qui prend soin de sa personne. Elle est très soignée de sa personne. $\rightarrow$ impeccable; FAM clean «. Galicizam nije reintegriran u prijevodu jer se prevoditeljica odlučila za riječ impeccable adj. ('nepogrešiv', 'besprijekoran', Putanec 1974:404), koja se dijelom svog značenjskog polja podudara s riječi soigné, ée adj.:

Biti doktor Blitwitz-Blithauer tu među vama, Blitvinima, Blatvijcima ili Hunima, upravo je tako neprijatno kao krezub tražiti svoje izgubljeno zubalo među zubatim barbarima, ili pomalo svrabljiv u prnjama kretati se među soigniranom blitvinskom gospodom, i to još više-manje žigosan kao cigo, a svaki kreten može da te identificira dao doktora Blitwitza, sina Šamike Mojsjeviča, jajaroša iz Strizirepa Donjeg Blitvinskog, gdje je đavao rekao svima laku noć! - Être le docteur BlitwitzBlithauer parmi vous, Blithuaniens, Blathuaniens et Houniens, c'est aussi déplaisant que de se promener tant soit peu galeux et en haillons parmi d'impeccables messieurs blithuaniens. N'importe quel crétin reconnaîtra en toi le docteur Blit-

16 SOIGNÉ, ÉE adj. n(3) (Le Petit Robert 1996:2103)

soanjiran $\mathrm{I} \mathrm{S}_{1 \mathrm{n}}(\neq 1 .)=$, njegovan, brižljivo uređen

(preko njem. soigniert njegovan)

var soigniran (Krleža)

$i z v$ soanjiranost $=$ njegovanost, dotjeran izgled . 
Biljana Stojaković: Reintegracija stilogenih galicizama u francuskom prijevodu...

FILOLOGIJA 70(2018), 107-133

witz, le fils de Schamika Moïsievitch, marchand d'oufs de Rognequeue, BasseBlithuanie, au diable vauvert! (BB) (pored hrv. njegovan)

Galicizam antišambr ${ }^{17}$ nije reintegriran $u$ francuskom prijevodu temeljem slobodne volje prevoditelja:

...i tko već ovdje nešto drži do ove vrste deklasirane podstanarke kao što sam ja, jer samo se deklasirane mizerije puštaju čekati po antišambrima čitave dane... - ... et qui tient compte ici d'une espèce de sous-locataire déclassé telle que moi? (BB) (pored hrv. predsoblje)

\subsubsection{Distribucijska asimetrija}

Pronašli smo niz stilogenih galicizama koji zbog proširenja značenja uzrokovanog boravkom $\mathrm{u}$ jeziku posredniku i različitosti u poimanju izvanjezične stvarnosti nemaju istu distribucijsku zastupljenost pa nisu ni mogli biti reintegrirani u sustav jezika davatelja. Ovdje navodimo samo dva.

\section{a) marš, maršovati}

Galicizam marš u primarnoj je adaptaciji preuzeo dva od ukupno 12 značenja francuskog modela marche, ${ }^{18}$ a galicizam marširati u primarnoj je adaptaciji preuzeo jedno značenje francuskog modela marcher. ${ }^{19}$

Međutim, kod Krleže se pojavljuje formalna i stilski obojena dubleta maršovati, koja u odnosu na značenje francuskog modela marcher ima sasvim drugačije značenje i distribuciju: izbaciti, istjerati nekoga iz kuće (uzvikom marš!) (Klaić 1978:851). U prijevodu na francuski nalazimo supstitut chasser:

A prije toga on mu je ugasio cigaretu na obrazu, a zatim ga je maršovao! - Et, auparavant, il lui avait éteint sa cigarette sur la joue, puis il l'avait chassé! (BB) // - ...da je svuče do gola $i$ da je zadavi onim njenim svilenim kombineom, nato-

17 ANTICHAMBRE, n.f. n(2) (Le Petit Robert 1996:91)

antišambr I $S_{1 \mathrm{n}}(\neq 1)=$. predsoblje

(preko njem. (das) Antischambre predsoblje)

izv antišambrirati ${ }^{\mathrm{d}(\mathrm{nj})}=$ čekati u predsoblju i moljakati; obijati tuđe pragove; dodvoravati se, biti ponizan < njem.: antischambrieren v.: čekati u predsoblju; pren. biti ropski ponizan.

18 MARCHE, n.f. n(12) (Le Petit Robert 1996:1351)

marš $^{\mathrm{d}(\mathrm{nj})} \mathrm{I} \mathrm{S}_{1 \mathrm{n}}\left(\neq \mathrm{II}\right.$. 3. $\mathrm{S}_{1 \mathrm{f}}, 7$.) = organizirani hod skupine ljudi (protestni marš, tihi marš); vojn. organizirano kretanje pješadije ili konjice; vojnička zapovijed: »stupaj!«; glazb. koračnica: pren. napredovanje

(preko njem. (der) Marsch pješačenje, hod; glaz. koračnica).

19 MARCHER, v. intr. n(11) (Le Petit Robert 1996:1352)

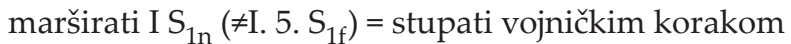

(preko njem. marschieren v. stupati vojničkim korakom). 
Biljana Stojaković: Reintegracija stilogenih galicizama u francuskom prijevodu...

FILOLOGIJA 70(2018), 107-133

pljenim još ljepljivim ljubavnim likerom, da je maršuje na ulicu odakle je $i$ došla, iz ovog njenog kretenskog stana, kamo se priženio kao došljak i bijeda od beskućnika... - Lui arracher ses vêtements et l'étrangler avec sa combinaison de soie, encore humide du suc amoureux, la jeter à la rue, la chasser de ce crétin d'appartement, où il est arrivé en intrus, nouveau marié et ambitieux, pauvre diable sans foyer, qui pensait se hisser jusqu'aux seigneuriales galeries blithuaniennes? (BB)

Imperativni uzvik Marš! u hrvatskom jeziku ima sljedeća značenja: »1. pov. vojn. zapovijed kojom je počinjao vojnički hod u austrougarskoj i jugoslavenskoj vojsci [ob. uz drugu pripremnu riječ: naprijed marš!! (danas samo: naprijed!)] 2. uzv. [...] b. u značenju: van! odlazi! c. riječ kojom se vrlo grubo tjera koga« (Anić 1998:517). Drugo značenje je vjerojatno preuzeto iz austr. njemačkog: marsch! (Gubi se! Odlazi!)

U francuskom prijevodu nalazimo različite supstitute galicizmu marš!:

Marš otale, jeste li me razumjeli, jer ako vas loćnem, linut će iz vaših crijeva meka nečist, kao da ste pače zgaženo! Marš otale...! - Fichez-moi le camp, vous m'avez compris, car si je vous rosse, c'est de la fiente qui glissera de vos boyaux, comme d'un canard écrasé! Allez, ouste, filez! (BB) - Marš ti, svinja stara! Šuft! - Eh, va donc, vieux cochon, canaille! (NRP)

Laku noć! Marš! - Bonne nuit! Allez, ouste! (BB) - Marš ti, tat zagorski! Vat'en, toi, espèce de voleur de Zagorje! (HBM)

\section{b) bagaža}

Jedno od značenja francuskog model bagage je i prtljaga. U primarnoj adaptaciji galicizam bagaža preuzeo je to značenje. Međutim, u sekundarnoj adaptaciji, pod utjecajem njemačkog jezika (Bagage, die- prtljaga; ološ (Uroić, Hurm 2002:78)) dobio je još jedno značenje, i to pogoršano: ološ, bagra. ${ }^{20}$ Uslijed proširenja broja značenja, točnije pejorizacije značenja, došlo je do distribucijske asimetrije u uporabi galicizma i modela, pa u prijevodu nalazimo niz supstituta:

- bagaža $\rightarrow$ racaille (»Vieilli. Populace méprisable $\rightarrow$ canaille, lie, plèbe«) (Le Petit Robert 1996:1846)

Svi ti ljudi, koje bagaža blitvanenska zove podrugljivo 'beauregardistima'... Ceux que la racaille blithuanienne apppelle ironiquement les 'beauregardistes'... (BB) // ...i, rastjeravši seljačku bagažu, očistio je taj naš zaostali blitvinski marvinski sajam... - ...et, mettant en fuite toute cette racaille paysanne, il a nettoyé notre vieille foire aux bestiaux blithuanienne... (BB) // - Uopće: ja vam kažem, ova naša blitvinska inteligencija, to je takva bagaža... - Dans l'ensemble, je vous

20 BAGAGE, n.m. n(3) (Le Petit Robert 1996:181)

bagaža $^{\delta(v \varphi)}($ Krleža) I Sın $(\neq 2$.) = prtljaga

II $\mathrm{S}_{2 \mathrm{n}}=$ ološ, bagra

(preko njem. (die) Bagage prtljaga; ološ). 
Biljana Stojaković: Reintegracija stilogenih galicizama u francuskom prijevodu...

FILOLOGIJA 70(2018), 107-133

le dis, notre intelligentsia blithuanienne est une telle racaille... (BB) // - Ta naša bagaža blitvinska sama ne zna što hoće... - Notre racaille blithuanienne ellemême ne sait pas ce qu'elle veut... (BB) - Željeznica smo sagradili više nego carska bagaža prije nas na našem tlu čitavo stoljeće! - Nous avons construit plus de voies ferrées que toute la racaille impériale ne l'avait fait avant nous dans ce pays pendant tout un siècle! (BB) // — ...da ta mračna bagaža osjeti otpor... ...pour que cette sombre racaille sente une résistance. (BB) // - A za tu bagažu to je memento: da smo tu! - Et pour la racaille, cela sert de rappel à l'ordre: 'Nous sommes là!' (BB) // - ...uz urlik protesta i hajdučkih zvižduka razularene i pijane silvestarske bagaže... - dans les clameurs de protestations et les sifflements sauvages de la racaille ivre de la Saint-Sylvestre... (BB) // - ...i ako su to elementarni principi svake političke strategije, onda znači, protiv Barutanskog, protiv njegove L.O.R.R.-bagaže... - S'il en est ainsi, si seule la masse peut agir sur la masse, s'il en est vraiment ainsi, cela veut dire que contre Baroutanski, contre sa racaille de l'O.L.O.T.P... (BB) // - ...velike ribe jedu male ribe, to je zakon naravi, fakinaža, plebs i bagaža nisu pozvani da govore u bilo čije ime... - Celui qui a tué sera tué, les gros poissons mangent les petits, c'est la loid de la nature. La racaille n'a pas droit à la parole, au nom de qui que ce soit... (BB) // - ...i ne ću se dati uplivisati od vaše novinarske bagaže... - ...je ne me laisserai pas influencer par votre racaille de journalistes... - Treba samo pogledati prou doknadnu! Ili četvrtu! Kakva su ono bagaža! - Prenons la première de réserve, par exemple! Ou la quatrième. De la racaille! (HBM) // - Ne isplati se niti zapovijedati toj lijenoj bagaži golom sabljom! - Cette racaille, il ne faudrait pas la commander sabre au poing. (HBM)

- bagaža $\rightarrow$ canaille (»Vieilli. Ramassis de gens méprisables ou considérés comme tels. $\rightarrow$ pègre, populace, racaille.«) (Le Petit Robert 1996:294)

Roman Rajevski, poznati blitvinski Genije, bio je za tu bagažu proorazredna senzacija. - ...Roman Raïevsky, le Génie blithuanien bien connu, était pour cette canaille une sensation de tout premier ordre. (BB) // A zahvalnost tih krava $i$ te bagaže? - Et la reconnaissance de ces vaches et de cette canaille? (PFL) // - ...on je čitao Rosenberga, on zna što je kolonijalna bagaža... - ...il a lu Rosenberg, il la connît, la canaille coloniale... (NRP) // - ...svu tu bagažu treba voditi u evidenciji... - Toute cette canaille... il faut l'avoir à l'ail... (NRP)

- bagaža $\rightarrow$ bande (»Groupe organisé et stable de personnes associées pour quelque dessein. Bande de malfaiteurs, de voleurs...«) (Le Petit Robert 1996:191) Ja sam spram tih stjenica i te patuljaste bagaže još uvijek, u najmanju ruku, jedan Franceso Sforza - Je suis, en comparison de ces punaises, de cette bande de nabots, un Francesco Sforza... (BB)

- bagaža $\rightarrow$ fripouille (»Vx. Racaille. Fam. Personne sans scrupules, qui se livre à l'escroquerie et à toutes sortes de trafics. $\rightarrow$ canaille...«) (Le Petit Robert 1996:975) 
Biljana Stojaković: Reintegracija stilogenih galicizama u francuskom prijevodu...

FILOLOGIJA 70(2018), 107-133

Da sam moralno i intelektualno lijena bagaža! - Que je ne suis, moralement et intellectuellement, qu'une paresseuse fripouille! (BB)

- bagaža $\rightarrow$ troupeau (»Péj. Troupe nombreuse et passive de personnes. 32; Fig. et par dénigrement, troupe, multitude de personnes...«) (Le Petit Robert 1996:2324)

Cijela ta Ingridina lirska akademska knjižeonička bagaža u njenom blesavom Louis XV-salonu... - Et tout ce troupeau académique, écrivassier, lyrique d'Ingrid qui fréquente son salon Louis $X V$... (BB)

- bagaža $\rightarrow$ écumeurs (»Celui qui écume. Fig. Un écumeur de marmites ou de table, un parasite...«) (Le Petit Robert 1996:717)

...sva ta bagaža koja se godinama hranila u mojoj kući... - ...tous ces écumeurs qui se sont nourris chez moi des années durant... (NRP)

- bagaža $\rightarrow$ grossiers personnages (»Incivil, malhonnête. Un grossier personnage«) (Littré 1878-1881:1053)

Bagaža bezobrazna! - Grossiers personnages, voyous!... (HBM)

\subsubsection{Različiti lingvistički statusi riječi}

Neki galicizmi nisu reintegrirani $u$ francuski prijevod zbog različitog lingvističkog statusa u francuskom i u hrvatskom jeziku.

\section{a) pisoar}

Dok je francuski model pissoir u regionalnoj i kolokvijalnoj uporabi, ${ }^{21}$ pa samim tim i stilski obilježen, galicizam pisoar u hrvatskom jeziku je općeprihvaćena riječ, specijalizirana u značenju: 'nužnik za muškarce'.

Iz tog razloga je $u$ prijevodu na francuski jezik izbjegnuta uporaba stilogenog pissoir i umjesto njega su upotrijebljeni supstituti urinoir i w.-c., ${ }^{22}$ koji nemaju nikakvu afektivnu vrijednost:

...od pisoara kavanskog čula (se) graja pijanih mornara... - ...l'on entendait, venant de l'urinoir, les voix avinées des matelots... (BB)

...probio sam se kroz uzane, sivim mramorom popločane hodnike (koji tako fatalno sjećaju na pisoare kavanske) do Sikstine. - après m'être subrepticement faufilé entre ces colonnes nauséabondes que des esclaves avaient nettoyées des ordures humaines de la nuit, navré par le total manque de goût de ces couloirs sans fin dallés d'un marbre gris qui ne peut qu'évoquer les w.-c. des cafés, j'arrivai à la Sixtine. (BB)

...onda zadovoljno gunđaju valcere, mokreći u podzemnom pisoaru kakvog prljavog noćnog lokala... - ...ils se mettent à chantonner des valses en se soulageant dans les urinoirs des boîtes de nuit, dans des sous-sols... (NRP)

21 »Région. (Nord) Édifice public où les hommes vont uriner« (Le Petit Robert 1996:1682).

22 Posuđenica iz engleskog jezika. 
Biljana Stojaković: Reintegracija stilogenih galicizama u francuskom prijevodu...

FILOLOGIJA 70(2018), 107-133

\section{b) karusel}

Jedno od značenja galicizma karusel je 'vrtuljak'. ${ }^{23}$ To značenje je sadržano $\mathrm{u}$ francuskom modelu carrousel, ali u regionalnoj uporabi. ${ }^{24} \mathrm{Da}$ bi u prijevodu na francuski jezik izbjegli ekspresivnu dimenziju dijalektalnosti, prevoditelji su galicizam karusel upotrijebljen u metaforičkom značenju u rečenici koja slijedi zamijenili francuskom riječi manège ${ }^{25}$ i na taj način ostvarili odgovarajuće metaforičko značenje:

Ljudi se tjeraju u slaboumnoj kružnici takozvanog socijalnouslovljenog karuzela $i$, kao na pravom sajamskom vrtuljku, ti su jahači na drvenim konjima društvenih predrasuda doista uvjereni da galopiraju nevjerojatnom brzinom u zatvorenom krugu 'uspjeha'. - Les gens se persécutent, là, dans le cercle imbécile de ce manège soi-disant socialement conditionné, là, sur la grande roue de la fête, et sur les chevaux de bois de préjugés sociaux ils croient dur comme fer qu'ils sont en train de galoper à toute vitesse dans le cercle fermé de réusssite. (NRP)

\section{c) hazarder}

Uporaba nekih francuskih modela hrvatskih galicizama je zastarjela, pa su takve riječi u francuskom jeziku stilski obilježene. $S$ druge strane, galicizam hazarder ${ }^{26}$ nema takav lingvistički status.

U prijevodu na francuski jezik izbjegnuta je riječ hasardeur koja nosi notu stilogenosti i stoga je galicizam hazarder zamijenjen sasvim drugom riječi, ovisno o kontekstu:

...Rajevski kao politički hazarder... - ...Rä̈evsky le joueur politique... (BB) // ...solidarnost, kakvu mogu da osjećaju samo hazarderi... - ...la solidarité que seuls les audacieux connaissent... (BB)

23 CARROUSEL, n.m. n(5) (Le Petit Robert 1996:312)

karusel I $S_{1 n}(\neq 1 ., 3 ., 5$.) = viteška igra u srednjem vijeku; vrtuljak (preko njem. (das) Karussel vrtuljak) var karuzel (Krleža).

24 »Région. (Belgique, Nord, Suisse, Canada) Manège forain« (Le Petit Robert 1996:312).

25 »Manège de chevaux de bois : attraction foraine où des animaux (des chevaux de bois à l'origine), des véhicules où prennent place les enfants, sont disposés sur une plateforme circulaire entraînée dans un mouvement rotatif« (Le Petit Robert 1996:1341).

26 HASARDEUX, EUSE adj. n(2) (Le Petit Robert 1996:1074) hazardan $\mathrm{I} \mathrm{S}_{0}=$ smion, opasan, riskantan

II $\mathrm{S}_{2 \mathrm{f}}=$ hazardna igra = igra na sreću s velikim novčanim ulozima $i z v$ hazarder $^{\mathrm{d}(\mathrm{nj})}($ Krleža) $=$ igrač na sreću, čovjek koji riskira preko njem. der Hasardeur igrač na sreću var hazardeur (Krleža) var hasardeur (Krleža) < njem. (der) Hasardeur igrač na sreću $i z v$ hazarderski. 
Biljana Stojaković: Reintegracija stilogenih galicizama u francuskom prijevodu...

FILOLOGIJA 70(2018), 107-133

\section{d) koketirati ${ }^{27}$}

Glagol koketirati ima sljedeća značenja: očijukati, namigivati; nastojati izazvati sviđanje (Klaić 1978:703). Taj glagol je replika francuskog modela coqueter, s kojim se preklapa u sljedećem značenju: Flirter. »Certains intellectuels allèrent jusqu'à coqueter avec l'anarchie«/Lecomte/ (Le Petit Robert 1996:472). Međutim, uporaba toga glagola u francuskom jeziku zastarjela je i stoga je u prijevodu izbjegnuta njegova reintegracija.

Sjedim u loži... koketiram s jednom nepoznatom ženom... - Je suis assis dans une loge... j'échange des cillades avec une femme inconnue... (BB)

\subsubsection{Stilske figure}

Analizirali smo figure ili mikrostrukture stila, kako ih naziva Škreb (1983:303), koje nisu reintegrirane u francuski jezik i pokušali utvrditi uzroke tomu.

\section{a) metafora}

Metafora je »mikrostruktura prenesena značenja« (Škreb 1983:325). Ona "podrazumijeva stvaralačko zapažanje sličnosti među različitim pojavama, štoviše identificiranje tih pojava, njihovo stapanje u nekom zajedničkom ili sličnom svojstvu« (Antoš 1974:82).

U procesu posuđivanja, galicizam kulisa se dijelom svog značenja znatno udaljio od značenja francuskog modela coulisse pod utjecajem njemačkog jezika kao jezika posrednika. ${ }^{28}$ U sljedećem primjeru upotrijebljen je galicizam kulisa u metaforičkom značenju »zamjena ili prikrivka autentičnog predmeta, varavost, prividnost « (Klaić 1978:765). Francuski model ne sadržava takvo značenje. Ono odgovara jednom od značenja francuske riječi décor prisutnom u francuskim izrazima (connâेtre, voir) l'envers du décor; c'est l'envers du décor; ce qui est derrière, l'apparence

27 COQUETER, v. intr. n(2) (Le Petit Robert 1996:472)

koketirati I $S_{1 n}(\neq 1)=$. očijukati, namigivati; nastojati izazvati sviđanje, svraćati pozornost na sebe

(preko njem. kokettieren v. očijukati).

COULISSE, n. f. n(3) (Le Petit Robert 1996:488)

kulisa $^{\mathrm{d}(\mathrm{nj})} \mathrm{I} \mathrm{S}_{1 \mathrm{n}}(\neq 2$.) = dekoracija na jednoj strani pozornice; prenes tajni poslovi II (potpuna promjena značenja) = žlijeb kroz koji prolazi jedan pomični dio mašine; dekorativni pomični element na pozornici koji služi za razgraničenje prostora scenske radnje; glazbena, zvučna kulisa u TV emisiji (preko njem. (die) Kulisse, zastor, zid na pozornici; hinter der $K \sim n$ potajno, krišom; (die) Musikkulisse, (die) Tonkulisse zvučna kulisa)

izv zakulisan = koji se odvija "iza kulisa", tajno $<$ njem. hinter der Kulisse. 
Biljana Stojaković: Reintegracija stilogenih galicizama u francuskom prijevodu...

FILOLOGIJA 70(2018), 107-133

illusoire), ${ }^{29}$ koju nalazimo kao metaforički ekvivalent u prijevodu:

...blitvinska je armada dekoracija, sedamnaest novih prospekata blitvanenskih... to je obična kulisa... - ...l'armée blithuanienne est la décoration, les dix-sept nouveaux prospectus blithuaniens... ce ne sont là que de vulgaires décors... ${ }^{30}$ (BB)

\section{b) ponavljanje}

»Ponavljanje najjače udara u oči kad riječ ili riječi koje pjesnik ponavlja neposredno slijede jedna iza druge ili jedne iza drugih« (Škreb 1983:316). U primjeru koji slijedi nekoliko puta se ponavlja galicizam kušovati. Krleža je na taj način naglasio karakter poniznih pukovnika. Prema svome značenju, galicizam kušovati nema nikakve poveznice s francuskim modelom coucher, ali ima s njemačkim glagolom kuschen: zašutjeti, ropski se pokoravati, na sve šutjeti. ${ }^{31}$

Iz tog razloga u prijevodu na francuski jezik nalazimo supstitut se tenir coi, coite, ali ne u obliku figure ponavljanja. Stoga smatramo da u prijevodu nije ostvaren odgovarajući stilski efekt:

i dok bi ta mizerija od pukovnika danas još mogla da drekne, sutra će kušovati kao što kušuju svi od Hunije do Koromandije i od Kurlandije do Blitve, sa svima svojim pukovnicima, svijestima, savjestima i znanostima, a zašto kušuju i pred kime kušuju, i dokle će kušovati, i po čemu se sve te stvari odvijaju na tako pasji način, tko bi mogao da odgoneta tajnu te bezidejne i blesave dresure. - Cette chiffe de colonel pourrait encore élever la voix, alors que demain tous se tiendront cois, comme tout le monde, de la Hounie à la Coromandie et de la Courlandie à la Blithuanie, avec tous leurs colonels, leurs sciences et leurs consciences. (BB)

\subsection{Sintaktostilistička razina}

Sintaktička stilistika proučava funkcionalno-stilsku i ekspresivnu markiranost stilema na sintaktičkoj razini. Prikazat ćemo ovdje neke prim-

29 Primjer iz literature: »Pour la foule de Marrakech, comme pour celles qui partout ailleurs regarderaient les images sans connaître l'enversdu décor, Churchill et de Gaulle apparaissant côte à côte cela signifiait que, bientôt, les armées alliées marcheraient ensemble à la victoire« (De Gaule 1956:215).

30 Ž. Klaić navodi da je prevoditeljica ovdje učinila pogrešku: prospekt je ruska posuđenica i znači 'širokaja ulica' (1982-1983:169).

31 COUCHÉ! interj. n (1) (Le Petit Robert 1996:485)

Kuš! d(nj) I $S_{0}=$ Lezi! (zapovijed psu)

II (potpuna promjena značenja) = u grubom jeziku: Jezik za zube!; biti kuš = šutjeti; ne micati se

(preko austr. Kusch! Zašuti!)

izv kušovati (Krleža) = držati jezik za zubima

(preko njem. kuschen v. zašutjeti, ropski se pokoravati; poleći (pas)). 
Biljana Stojaković: Reintegracija stilogenih galicizama u francuskom prijevodu...

FILOLOGIJA 70(2018), 107-133

jere uporabe nominativne rečenice ${ }^{32}$ kao postupka ekspresivne sintakse i načine njezine prilagodbe francuskom prijevodu.

»U nominativnim rečenicama nominativna riječ ili sintagma preuzima na sebe predikativnost, a opća semantika tih rečenica jeste postojanje predmeta ili predmetno predstavljene pojave, radnje, stanja « (Švedova Lopatin 1989:454). U takvim rečenicama »ponekad glagol kao da je prisutan $\mathrm{u}$ formi imenice - on predaje imenici svoj smisao i dio svojih funkcija« (Dubois, Edeline 1981:134, citirano prema Katnić-Bakaršić 1999:95).

U primjeru koji slijedi nalazimo nominativnu rečenicu Blondina. Ova figura nominalizirano i metaforički predstavlja Europu. Prevoditelji na francuski jezik primijenili su drugačiji postupak, tj. parcelaciju:

Djevojka. Blondina. To je Evropa. - Une jeune fille. Blonde. C'est l'Europe. (BB)

Ekspresivna vrijednost nominativne rečenica Repriza. u odlomku koji slijedi leži u njezinom ironičnom naglašavanju činjenice o ponavljanju kriminalnih radnji, tj. ukazivanju na nepopravljivost karaktera čovjeka sklonog kriminalu. $U$ francuskom prijevodu galicizam repriza ${ }^{33}$ nije reintegriran, nego se prevoditelj odlučio za riječ récidive čije značenjsko polje uključuje i značenje 'djelo (kažnjivo) u povratu' (récidive f. povrat, ponovni napad(aj), povratak bolesti, ponovni pad (prijestup), recidiva; djelo (kažnjivo) u povratu (Putanec 1974:712)), ali ne u funkciji nominativne rečenice, nego u kumulaciji, u kojoj se gubi ekspresivna snaga nominativne rečenice:

Proa krađa, druga krađa, proa provala, treća krađa, i sasvim prirodno: pravne i zakonske posljedice tih protuzakonitih i protupravnih ispada. Prve tri godine. Repriza. Provala u draguljarnu. Druga osuda: sedam godina. - Un premier vol, un deuxième vol, un cambriolage, trois cambriolages, et bien entendu les conséquences légales et juridiques de ces actes d'outrage envers la justice et les lois. Les premiers trois ans. Cambriolage d'une bijouterie. Récidive, deuxième condamnation, sept ans. (NRP)

32 U sljedećem primjeru Krleža koristi niz nominativnih rečenica koje dočaravaju dinamiku jedne situacije. U prijevodu na francuski jezik primijenjen je isti sintaktostilistički postupak i postignut ekspresivni ekvivalent.

Stanka. Konjak. Cigareta. Dim. Još dva-tri dima. Konjak. - Un silence. Cognac. Cigarettes. Fumée. Deux ou trois bouffées encore. Cognac. (BB).

REPRISE, n.f. n(9) (Le Petit Robert 1996:1944)

repriza $\mathrm{I} \mathrm{S}_{1 \mathrm{n}}\left(\neq \mathrm{I} .2\right.$. $\left._{1 \mathrm{~F}}, \mathrm{II} .2\right)$ = ponovna izvedba kazališne predstave; ponavljanje teme u glazbenom djelu; uopće svaki ponovljeni događaj

(preko njem. (die) Reprise ponavljanje)

izv reprizni prid. 


\section{Zaključak}

U istraživanju reintegracije Krležinih galicizama na stilističkoj razini $\mathrm{u}$ francuskom prijevodu njegovih djela analizirali smo stilogene galicizme i uzroke preprekama njihovoj reintegraciji: ograničenja uzrokovana različitostima u morfosintaktičkim sustavima dvaju jezika, relativnost značenja riječi, različiti lingvistički statusi riječi, dijakronijski diskontinuitet, utjecaj jezika posrednika i prevoditeljska sloboda.

Tako smo na fonostilističkoj razini utvrdili upotrebu vlastitog imena u transkripcijskom obliku francuskog izgovora imena radi postizanja lokalnog kolorita (Öžen). U francuskom prijevodu nije postignut odgovarajući effet par évocation, jer čitatelju francuskog teksta samo ime Eugène u sebi ne nosi notu stilogenosti. Na morfološkoj razini pronašli smo slučaj u kojem stilogeni hrvatski pridjev $u$ augmentativnom obliku (naivčina) nije reintegriran zbog ograničenja morfološkog sustava francuskog jezika pa je u prijevodu izostao prijenos ekspresivne vrijednosti izražene tim galicizmom. Na semantostilističkoj razini analizirali smo uporabu francuskih posuđenica, adaptiranih i neadaptiranih, u funkciji postizanja effet par évocation, tj. karakterizacije likova koji pripadaju višoj društvenoj klasi (npr. kuzina, attituda). U francuskom prijevodu takve riječi gube svoju stilogenost. Neki stilogeni galicizmi nisu reintegrirani u francuski jezik zbog razlike u lingvističkom statusu između modela i replike (npr. pisoar) ili zbog dijakronijskog diskontinuiteta (npr. hazarder). U korpusu smo pronašli i nekoliko primjera stilskih figura koje nisu reintegrirane $\mathrm{u}$ francuski jezik. Uzroci tomu leže u semantičkim razlozima (npr. promjena značenja riječi kulisa, koja je upotrijebljena u metaforičkom značenju) ili u pristupu prevoditelja (npr. ignoriranje figure ponavljanja riječi kušovati).

Istraživanje $\mathrm{u}$ ovom radu pokazalo je da se samo analizom reintegracije posuđenica $u$ ishodišni jezik može steći prava slika o stupnju njihove prilagodbe jeziku primatelju. Naime, jednostranom analizom posuđenica $\mathrm{u}$ jeziku primatelju ne stječe se potpuno saznanje o opsegu promjena koje posuđenice pretrpe u prilagodbi stranome jeziku. Nalazi istraživanja govore u prilog brojnim preprekama reintegraciji. I upravo analizom tih prepreka dolazi se do dragocjenih spoznaja o razini prilagodbe posuđenica novom jezičnom okruženju te o stupnju udaljenosti od kolijevke jezika davatelja. To je bila nakana ove studije. 
Popis kratica i simbola sintetičkih formula na semantičkoj razini (Filipović 1986:180):

$\begin{array}{ll}\mathrm{n} & \text { broj značenja modela } \\ \mathrm{S} & \text { semantička razina } \\ \mathrm{I} & \text { primarna adaptacija } \\ \mathrm{II} & \text { sekundarna adaptacija } \\ \mathrm{S}_{0} & \text { nulta semantička ekstenzija } \\ \mathrm{S}_{1} & \text { suženje značenja } \\ \mathrm{S}_{2} & \text { proširenje značenja } \\ \mathrm{S}_{1 \mathrm{n}} & \text { suženje značenja u broju } \\ \mathrm{S}_{1 \mathrm{f}} & \text { suženje značenjskog polja } \\ \mathrm{S}_{2 \mathrm{n}} & \text { proširenje značenja u broju } \\ \mathrm{S}_{2 \mathrm{f}} & \text { proširenje značenjskog polja } \\ \mathrm{d}(\mathrm{nj}) & \text { utjecaj njemačkog jezika kao jezika posrednika } \\ \neq & \text { simbol nejednakosti; iza njega se rednim brojem navode } \\ & \text { značenja koja su preuzeta iz jezika davatelja u jezik primatelj. }\end{array}$

Pokraćenice iz hrvatskog jezika:

austr. austrijski njemački jezik

glazb. iz glazbene terminologije

izv. izvedenica

njem. njemački jezik

pren. preneseno (značenje)

prid. pridjev

uveć. uvećanica

var. varijanta

vojn. iz vojničke terminologije.

Pokraćenice iz francuskog i njemačkog jezika:

interj. interjection (riječ uzvik na francuskom jeziku)

adj. adjectif (imenica pridjev na francuskom jeziku)

n.f. nom féminin (francuska imenica ženskog roda)

n.m. nom masculin (francuska imenica muškog roda)

v. verb (imenica glagol na njemačkom jeziku)

v.intr. verbe intransitif (neprijelazni francuski glagol). 


\section{Literatura}

Andrić, Dragoslav. 1976. Dvosmerni rečnik srpskog žargona i žargonu srodnih reči i izraza. Beograd : Beogradski izdavačko-grafički zavod. 466 str.

Anić, Vladimir. 1998. Rječnik hrvatskog jezika. Zagreb : Novi Liber. 1439 str.

Anić, Vladimir, Ivo Goldstein. 2007. Rječnik stranih riječi. Zagreb : Novi Liber. 1494 str.

Antoš, Antica. 1974. Osnove lingvističke stilistike. Zagreb : Školska knjiga. 159 str.

Bally, Charles. 1951. Traité de Stylistique Française. Librairie Georg \& Cie Genève - Paris Kliecksieck. 264 str.

Crystal, David. 1994. The Cambridge Encyclopedia of Language. Cambridge : Cambridge University Press. 1357 str.

De Gaule, Charles. 1956. Mémoires de guerre - L'Unité : 1942-1944 (tome II), éd. Plon, Paris. 511 str.

Dubois, Jean, Édeline, Francis, etal. 1981. A General Rhetoric, Trans. by Paul B. Burrelland Edgar M. Slotkin. Baltimore: Johns Hopkins University Press. Trans. of 1971. Rhétorique générale: Langue et Langage. Paris: Librairie Larousse. 206 str.

Filipović, Rudolf. 1986. Teorija jezika u kontaktu. Zagreb : Školska knjiga. 324 str.

Franolić, Branko. 1975. L'influence de la langue française en Croatie, d'après les mots empruntés, Aspect sociohistorique. Paris : Nouvelles éditions Latines. 157 str.

Franolić, Branko. 1976. Les mots d'emprunt Français en Croate. Paris : Nouvelles Editions Latines. 216 str.

Haugen, Einar. 1950. The Analysis of Linguistic Borrowing. Language Vol. 26, 210-231.

Ivir, Vladimir. 1985. Teorija i tehnika prevođenja. Sremski Karlovci : Centar Karlovačka gimnazija. 159 str.

Guberina, Petar. 1967. Stilistika. Zagreb : Zavod za fonetiku Filozofskog fakulteta u Zagrebu. 130 str.

Jakobson, Roman. 1959./2004. On linguistic aspects of translation. Lawrence Venuti (ed.) The Translation Studies Reader, 2nd edition, 138-143.

Jakobson, Roman. 1960./1987. Linguistics and Poetics. Krystyna Pomorska (ed.) Language in Literature. The Belknap Press of Harvard University Press. Cambridge, Massachusetts. London, England. 62-94.

Katnić-Bakaršić, Marina. 1999. Lingvistička stilistika. Budapest : Open Society Institute. 137 str.

Klaić, Bratoljub. 1978. Rječnik stranih riječi. Tuđice i posuđenice. Zagreb : Nakladni zavod Matice hrvatske. 1456 str. 
Klaić, Bratoljub. 1972. Leksičke bilješke uz jedan Krležin tekst. Republika XIX/1963, 7-8. 4 str.

Klaić, Željko. 1982-1983. Le sort des emprunts au français dans la version française du Banquet en Blithuanie de Miroslav Krleža (I, II). SRAZ 27. 72 str.

Krleža, Miroslav. 1963. Hrvatski bog Mars. Sarajevo : Svjetlost izdavačko preduzeće. 320 str.

(Krleža) Karleja, Miroslav. 1964. Banquet en Blithuanie. Paris : CalmannLévy. 614 str.

(Krleža) Karleja, Miroslav. 1966. Je ne joue plus. Paris : Éditions du Seuil. 268 str.

(Krleža) Karleja, Miroslav. 1971. Mars Dieu Croate. Paris : Calman-Lévy. 260 str.

(Krleža) Karleja, Miroslav. 1988. Le Retour de Philippe Latinovicz. Paris : Calman-Lévy. 250 str.

Krleža, Miroslav. 2000. Banket u Blitvi. Zagreb : Naklada Ljevak. 735 str.

Krleža, Miroslav. 2001. Na rubu pameti. Zagreb : Naklada Ljevak. 275 str.

Krleža, Miroslav. 2002. Povratak Filipa Latinovicza. Zagreb : Profil. 384 str.

Lauer, Reinhard. 2013. Miroslav Krleža - hrvatski klasik. Zagreb : Naklada Ljevak. 235 str.

Le Petit Robert $=$ Le Nouveau Petit Robert de la langue française. 1996. Paris : Le Robert. 2550 str.

Littré, Émile. Dictionnaire de la langue française. 1878-1881. Hachette.

Pranjić, Krunoslav. 1986. Jezikom i stilom kroza književnost. Zagreb : Školska knjiga. 266 str.

Putanec, Valentin. 1974. Francusko-hrvatski ili srpski rječnik. Zagreb : Školska knjiga. 975 str.

Radovanović, Milorad. 1979. Sociolingvistika. Beograd : Beogradski izdavačko-grafički zavod. 160 str.

Silić, Josip. 2006. Funkcionalni stilovi hrvatskoga jezika. Zagreb : DISPUT. 304 str.

Slawinski, Janusz. 1989. Slownik terminow literackich. Wrozlaw, Warsawa, Krakow, Gdansk, Lodz : Zaklad Narodowy im. Ossolińskich. 706 str.

Škreb, Zdenko, Ante Stamać. 1983. Uvod u književnost. Zagreb : Grafički zavod Hrvatske. 818 str.

Švedova, Nataliâ Ûl'evna, Vladimir Vladimirovič Lopatin. 1989. Slovo $i$ grammatičeskie zakony jazyka: Glagol. Moskva : »Nauka«. 639 str.

Uroić, Marija, Antun Hurm. 2002. Njemačko-hrvatski rječnik. Zagreb : Školska knjiga. 1008 str. 


\section{Réintégration des Galicismes Ayant la Valeur Stylistique en Traduction Française des Euvres Littéraires de Miroslav Krleža}

\section{Résumé}

Dans l'étude de la réintégration des galicismes de Krleža au niveau stylistique en traduction française de ses œuvres nous avons analysé les galicismes stylogéniques et les causes d'obstacles à leur réintégration: les contraintes causées par les différences entre les systèmes morphosyntaxiques de deux langues, la relativité de la signification des mots, les statuts linguistiques différents des mots, la discontinuité diachronique, l'influence de la langue intermédiaire et la liberté de traduction.

Au niveau phonostylistique nous avons détecté que l'auteur a utilisé dans un de ses romans un nom propre dans la forme transcriptionnelle d'après la prononciation française de ce nom pour obtenir de la couleur locale (Öžen). Dans la traduction française, l'effet par évocation correspondant n'a pas été atteint parce que le nom Eugène en français ne porte pas de note stylistique.

Au niveau morphologique, nous avons trouvé un cas où le galicisme ayant des nuances stylistiques dans la forme augmentative (naivčina) n'était pas réintégré à cause des limitations du système morphologique français, donc la traduction excluait la transmission de la valeur expressive exprimée par ce galicisme.

$\mathrm{Au}$ niveau sémantique, nous avons analysé l'utilisation des emprunts français, adaptés et inadaptés, pour obtenir l'effet par évocation, c'est-à-dire caractériser des personnages appartenant à une classe supérieure de la société (par ex. kuzina, attituda). Dans la traduction française ces mots perdent leur valeur expressive.

Certains gallicismes stylogéniques ne sont pas réintégrés en français en raison de la différence de statut linguistique entre le modèle et la réplique (par ex. pisoar) ou en raison de la discontinuité diacronique (par ex. hazarder).

Dans le corpus, nous avons également trouvé quelques exemples de figures de style qui n'ont pas été réintégrées en français pour des raisons sémantiques (par exemple, le changement de signification du mot kulisa utilisé dans le sens métaphorique) ou à cause de la méthode en traduction (par exemple, la négligence de répétition stylistique du mot kušovati).

Les résultats de la recherche montrent de nombreux obstacles à la réintégration, et c'est seulement en analysant les causes de ces obstacles qu'on obtient des indications précieuses sur le niveau d'ajustement des emprunts au nouvel environnement linguistique et sur le degré de distance par rapport à la langue prêteuse. En d'autres mots, une analyse des emprunts conduite seulement dans la langue emprunteuse ne permet pas d'acquérir pleinement la 
Biljana Stojaković: Reintegracija stilogenih galicizama u francuskom prijevodu...

FILOLOGIJA 70(2018), 107-133

connaissance de l'étendue des changements que les emprunts subissent en adaptant à une langue étrangère. C'était le but de cette étude-ci.

Ključne riječi: leksičko posuđivanje, galizicam, jezik posrednik, stilogenost, Krleža, reintegracija, prepreka

Mots clés: emprunt lexical, galicisme, langue intermédiaire, valeur stylistique,

Krleza, réintégration, obstacle 